An earlier report was published at www.cmaj.ca on Sept. 1, 2005.

Canada dispatched ships loaded with medical and relief supplies, Red Cross volunteers, and a search-and-rescue team including emergency physicians to help Americans on the Gulf Coast who were devastated by Hurricane Katrina.

The hurricane struck Aug. 29 , levelling huge swaths of Louisiana, Alabama and Mississippi, and forcing the evacuation of New Orleans. US officials declared a national public health emergency and President George Bush's administration was criticized for a faltering re- lief effort that left thousands stranded for days.

Canada began helping within the week. "Neighbours helping neighbours applies every bit as much outside of our borders," said Prime Minister Paul Martin as he praised US relief efforts.

The Public Health Agency of Canada sent blankets, gloves, gowns, batteries, needles, surgical dressings, bandages, tongue depressors and other supplies from its emergency stockpile.

Three naval ships and one Coast Guard vessel, 3 Sea King helicopters and about 1000 sailors set sail from Halifax on Sept. 6.

Quebec supplied cots to the American Red Cross for evacuated refugees.

Vancouver's Urban Research and Rescue team, including Dr. Mike Flesher who helped with medical triage, rescued 119 people stranded in St. Bernard Parish, La.

The Canadian Red Cross, which is sending more than 100 volunteers, is accepting donations for Katrina relief efforts at www.redcross.ca or 800418 1111. — Laura Eggertson, CMAJ

\title{
Flu Pandemic
}

\section{"Unrealistic" to share North American antiviral supply}

As the WHO was orchestrating a massive international effort to share influenza antiviral treatment in the developing world, Canada and the US decided not to create a common North American stockpile.

Oseltamivir (Tamiflu) could help to reduce illness and death in the event of an avian flu pandemic, but supply will be far short of demand if a pandemic hits in the next few months.

It is "unrealistic" with limited supplies "to start talking about sharing," said Dr. Karen Becker, a senior health adviser with the US Emergency Preparedness Department, during a dialogue on US-Canada Joint Preparations for an Avian Influenza Pandemic held Aug. 23.

So far, the US has enough oseltamivir to treat 2.3 million people, while Canada has supplies for 1.6 million citizens.

The incentive to have sufficient supplies is huge. If a pandemic hits, medical costs, outpatient visits, drug purchases and time off work are "conservatively estimated at $\$ 10$ to $\$ 24$ billion," says Dr. Arlene King, the Canadian Public Health Agency's director of immunization and respiratory infectious diseases.

Roche Holdings, the world's only manufacturer of oseltamivir, has agreed to donate 3 million treatment courses to a WHO stockpile for use at the initial site of an emerging pandemic.

Philippine's Health Secretary Dr. Francisco Duque told reporters that WHO and its member states should "bond together and exact pressure to make sure that not just one drug manufacturer is going to produce the antiviral." He said that Roche's monopoly on drug production is "bordering on the immoral."

Developing countries are allowed to manufacture generic copies of patented drugs in the event of a medical emergency. However, after initial speculation in Thailand in March this year, no further talk of generic development has emerged.

Some countries are also researching ways to produce a vaccine against avian influenza. Because the final genetic makeup of a pandemic virus is un-

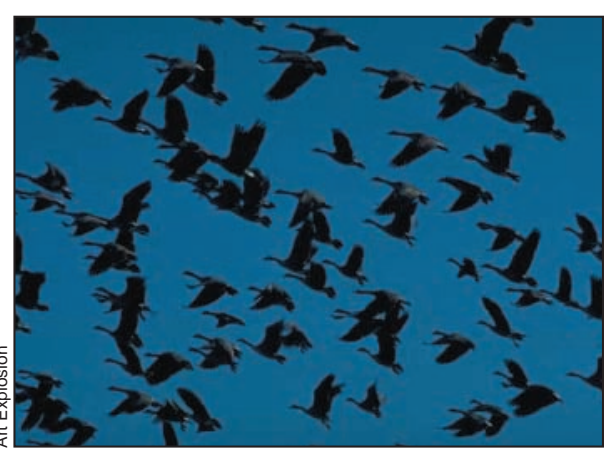

Infected wild birds are migrating across Asia, Russia, Siberia and Kazakhstan.

known, it cannot be produced beforehand. However, the US is producing "enough eggs to ramp up vaccine production quickly," says Becker. The US is also investing in "cell culture vaccines" that could produce vaccines "more rapidly and in higher quantities.

Dead seagulls in northern Finland have raised fears that avian flu may have already entered Europe. Officials fear further spread to Europe, the Middle East and Africa as tens of millions of birds nesting in Siberia migrate to warmer climates. - Sally Murray, CMAJ 